\title{
NAZÎM YAHYA'NIN BİR AŞK HİKÂYESİ: "DÂSTÂN-I HECR Ü VİSÂL"
}

\section{İsmail YILDIRIM*}

$\ddot{O} \mathbf{z}$

XVIII. asır şairlerinden Nazîm Yahya (ö. 1727) Klâsik Türk edebiyatı dairesinde yetişmiş, devrinin önde gelen simalarından birisidir. İstanbul'un Kumkapı semtinde doğan şairin asıl adı Yahya'dır. Şair aynı mahlası kullananlardan ayırt edilmek için Nazîm Yahya Çelebi ismiyle anılmıştır. Arapça ve Farsça'yı iyi bilen şair, özellikle musikî alanında devrinin önde gelen musikîşinaslarından biridir. Ayrıca, Divan şiirinde çok na't yazan şairler arasında yer alan Nazîm'in tek eseri, beş ayrı divandan oluşan Divan- $\iota$ Belâgat-unvân-ı Nazîm'idir. Söz konusu Divan, klâsik edebiyatımızın en hacimli divanlarından birisidir.

Şairin Dâstân-ı Hecr ü Visâl adlı mesnevisi, 1668 tarihinde tamamladığı birinci divanında yer almakta ve 160 beyitten meydana gelmektedir. Sade ve akıcı bir üslûpla kaleme alınan mesnevide genel olarak; Hecr ve Visâl'in aşk1, rakiplerin bu aşka olan tahammülsüzlükleri, iki sevgilinin ayrılması ve âşığın başından geçen maceraları konu edinmektedir. Hikâye, klâsik mesnevi tarzı tertip ve hususiyetlerini içerisinde barındırmakta; başından sonuna tahkiyevî anlatımın esrarengiz havası içinde geçmektedir. Ayrıca mesnevi içerisinde konunun akışına uygun ve tekdüzeliği kırmak maksadıyla kaleme alınan bir gazel, bir de rubaî bulunmaktadır. Bu çalışmada önce Nazîm Yahya'nın hayatı ve edebî şahsiyeti hakkında bilgi verilecek; sonra yukarıda adı geçen hikâye incelenerek mesnevinin transkribe edilmiş metni sunulacaktır.

Anahtar Sözcükler: Nazîm Yahya, Divan şiiri, Mesnevi, Dâstân-1 Hecr ü Visâl.

\section{A LOVE STORY BY NAZÎM YAHYA: "DÂSTÂN-I HECR Ü VİSÂL"}

\begin{abstract}
Being one of the poets of $18^{\text {th }}$ century, Nazîm Yahya (d. 1727) is one of the leading faces of the era who was educated in Classical Turkish literature. Born in Kumkapi district of Istanbul, the poet's real name is Yahya. The poet was referred to as Nazîm Yahya Çelebi so that he can be differentiated with those using the same pseudonym. Being able to speak Arabic and Persian, the poet is particularly one of the prominent music lovers of the era. Furthermore, being one of the poets who write lots of odes, Nazîm has Divan-ı Belâgat-unvân-ı Nazîm, which consists of five different divans. This Divan is one of the most voluminous divans of the Classical literature.

The poet's mesnevi called Dâstân-ı Hecr ü Visâl is included in the first divan which was completed by him in 1668 and it consists of 160 couplets. Written with a simple and fluent style, that mesnevi includes the love of Hecr and Visâl, intolerances of the rivals towards that love, separation of those lovers and the adventures of the lover in general. The story contains classical mesnevi style disposition and intimacies; and it is in a mysterious atmosphere
\end{abstract}

\footnotetext{
Arş. Gör.; Kırıkkale Üniversitesi Fen-Edebiyat Fakültesi Türk Dili ve Edebiyatı Bölümü,
} ismailyildiriim@gmail.com. 
in its narration from the beginning to the end. There are also a gazelle and a rubaie which is written in conformity with the flow of the subject and to disrupt uniformity inside the mesnevi. And this study will primarily give information about Nazîm Yahya's life and literary personality and then examine the abovementioned story and give the transcribed version of the mesnevi.

Keywords: Nazîm Yahya, Divan poetry, Mesnevi, Dâstân-1 Hecr ü Visâl.

\section{Giriş}

Arapça "ŝ̀, n, y" üçlü kökünden türeyen ve "ikişer ikişer" manasına gelen "mesnen" kelimesinin bir nisbet şekli gibi görünen mesnevi kelimesi, Arapçada kullanılmamıştır. ${ }^{1}$ İştikakı itibariyle Arapça olan mesnevi tabiri, Farsçada genelleşerek yayılmış ve daha sonra Türkçeye geçmiştir. ${ }^{2}$ Beyit sayısı bakımından hiçbir kısıtlayıcı kurala bağlı değildir. Gerek beyitler arasında kafiye bağlantısı bulunmaması, gerek beyit sayısının sınırlı olmaması, şairlerin işledikleri konuyu istedikleri kadar genişletmelerine imkân sağlamış; bu yüzden de çok kullanılan bir nazım şekli olmuştur. ${ }^{3}$

Klâsik Türk edebiyatı ürünlerine bakıldığında mesnevi nazım şekli ile meydana getirilen birçok eser görülür. Farklı konular etrafında kaleme alınan bu eserler kimi zaman aşk konulu, kimi zaman destansı, kimi zaman ahlâkî vs. temalar etrafında şekillenmiştir. $\mathrm{Bu}$ tarz mesnevilerin konuları çoğu zaman Arap ve Fars edebiyatından alınmakla beraber, şairlerimiz onları tercüme eder veya yeniden yazarken ekleme yahut çıkarmalar yapmış; böylece şiirdeki ustalıklarını ve hünerlerini göstermeye çalışmışlardır. Hatta şairler bu vadide beş mesnevi yazarak bir hamse ${ }^{4}$ oluşturma gayreti içerisine de girmişlerdir.

Nazîm Yahya (ö. 1727)'nın kaleme aldığı Dâstân-ı Hecr ü Visâl adlı mesnevi "iki kahramanlı aşk hikâyeleri” adı altında değerlendirilebilir. Hikâyenin kahramanının Nazîm olduğu anlaşılan metinde, hikâye kahramanlarının başından geçen maceralar anlatılır. Klâsik Türk edebiyatının farklı dönemlerinde bu tür eserler kaleme alınmış olup, devrin genel vasıflarını yansıtan edebî eserler içinde aşk

\footnotetext{
${ }^{1}$ Ahmet Ateş, "Mesnevî” İslâm Ansiklopedisi, MEB Yayınları, C. 8, İstanbul 1971, s. 127.

2 Âmil Çelebioğlu, Türk Edebiyatında Mesnevi [XV. Yüzyıla Kadar], Kitabevi Yay., İstanbul 1999, s. 21

3 İsmail Ünver, "Mesnevi”, Türk Dili Türk Şiiri Özel Sayısı II (Divan Şiiri), S. 415-416-417/Temmuz-Ağustos-Eylül, Ankara 1986, s. 432.

${ }^{4}$ Hamse hakkında geniş bilgi için $b k$. Mehmet Arslan, Türk Edebiyatı'nda Hamse, Türkiye Araştırmaları Literatür Dergisi, C. 5, S. 9, 2007, s. 305-322; Tahsin Yazıc1-Cemal Kunaz, "Hamse" TDV İslâm Ansiklopedisi, İstanbul 1997, C. 15, s. 499-500; Hüseyin Ayan, Divan Edebiyatında Hamseler, AÜ Edebiyat Fakültesi Araştırma Dergisi, (Ahmed Caferoğlu Özel Sayısı), S. 10, Ankara 1979, s. 87-100.
} 
mesnevileri ön planda tutulmuştur. Hamdullah Hamdi (ö. 1503)'nin Yûsuf $u$ Züleyhâ's1 ${ }^{5}$, Fuzulî (ö. 1556)'nin Leylâ vü Mecnûn'u', Şeyh Galib (ö. 1799)'in Hüsn ü $A s ̧ k^{\prime} 1^{7}$ üslup ve muhteva açısından dönemlerinin en yetkin aşk mesnevileri arasında yer alır.

Aşk konusunun işlendiği bu hikâyelerin çoğu maddî aşk1 ve bu uğurda âşıkların başından geçen maceraları konu alan mesnevilerdir. En güzel örnekleri XIV, XV ve XVI. yüzyıllarda kaleme alınan bu eserler arasında Yûsuf u Züleyhâ, Leylâ vü Mecnûn, Husrev ü Şîîn, Ferhâd u Şîrîn, Varaka ve Gülşah, Cemşî̀d ü Hûrşîd, Vâmık u Azrâ, Süheyl ü Nevbahâr en çok işlenen hikâyeler arasında yer almaktadır. ${ }^{8}$ Aşk mesnevileri iki âşık kahramanın aşk merkezinde yaşadıklarının konu edildiği vaka esasına dayalı eserlerdir. Vaka herhangi bir alakayla bir arada bulunan veya birbirleriyle ilgilenmek mecburiyetinde kalan fertlerden en az ikisinin karşılıklı münasebetlerinin tezahürüdür. ${ }^{9}$

Nazîm'in Dâstân-ı Hecr ü Visâl'i de söz konusu mesneviler gibi vaka esasl1, şairin başından geçen hadiseleri konu edinen bir hikâyedir. Mesnevi, İstanbul'da Takvîm-i Vakâyi' Matbaası'nda 1257 (1841) tarihinde basılan ve beş ayrı divandan meydana gelen "Dîvân-ı Belâgat-unvân-ı Nazîm"10 isimli külliyatın birinci divanının 145-150. sayfaları arasında yer almaktadır. Eseri incelemeye geçmeden önce meydana getiren şair hakkında bilgi vermek uygun olacaktır.

\section{Nazîm Yahya Çelebi}

İstanbul'un Kumkapı semtinde Gedikpaşa'da dünyaya gelen şair, bu sebeple Gedikpaşalı Nazîm diye anılmıştır. Kaynaklarda ${ }^{11}$ Nazîm'in vefatında seksen yaşlarında olduğu belirtildiğine göre 1059 (1649) civarında doğduğu söylenebilir. Divanındaki bir tarih manzumesinden ${ }^{12}$ anlaşıldığına göre babası 1103 (1692) vefat eden Ali Çelebi'dir. Şiir ve

\footnotetext{
${ }^{5}$ Naci Onur, Hamdi, Yûsuf u Züleyhâ, Akçağ Yayınları, Ankara 1991.

${ }^{6}$ Hüseyin Ayan, Leylâ vü Mecnûn, Dergâh Yayınları, İstanbul 2011.

${ }^{7}$ Muhammet Nur Doğan, Hüsn ü Aşk, OOtüken Yayınları, İstanbul 2002.

${ }^{8}$ Mustafa Uzun, “Aşk" (Edebiyat, Kültür ve Sanat), Di̇A C. 4, TDV Yay., İstanbul 1991, s. 19.

${ }^{9}$ Şerif Aktaş, Roman Sanatı ve Roman İncelemesine Giriş, Akçağ Yayınları, Ankara 2005, s. 46.

${ }^{10}$ Yahya Nazim, Divan-ı Belâgat-unvân-ı Nazîm, Takvîm-i Vakâyi’ Matbaası, İstanbul 1247.

${ }^{11}$ Rûşen Ferit Kam, Bestegâr Şair Nazim, Hilâl Matbaası, İstanbul 1933, s. 4.

${ }^{12}$ Nazîm girye-künân fevtine didüm târîh

"Cihânda Kevser içe dembedem Ali Çelebi" (1103) [Divan, s. 144]
} 
musikiye olan kabiliyetinin anlaşılması üzerine Enderun'a alınan şair, burada iyi bir tahsil görmüş, Arapça ve Farsça öğrenmiştir. ${ }^{13}$

Gençlik yıllarında Mevlevî tarikatına intisap ederek üç yıl kadar Galata Mevlevihanesi şeyhi Arzî Mehmed Dede'nin hizmetinde bulunduğu, daha sonra Edirne Mevlevihanesi şeyhi Neşatî Dede'ye bağlandığı, onlardan edebiyat ve musiki konularında faydalandığı haklarında yazdığı medhiyelerden anlaşılmaktadır. Edirne Mevlevihanesinin Neşâtî Dede tarafından tamiri vesilesiyle söylediği bir tarihten hareketle onun postnişinlikte bulunduğu 1670-1674 yılları arasında bir müddet Edirne'de yaşadığını tahminen söylemek mümkündür. ${ }^{14}$

Şairin ilk mahlası Halîm'dir. Safâyî Tezkiresi'nde yer alan “Nice zaman Halîm tahallüs edip ba'dehu Nazîm'de âheng-i karar ihtiyar etmişdir"15 ifadesi bu hükmü doğrular niteliktedir. Daha sonra Neşatî tarafından kendisine Nazîm mahlası verilmiştir. Şairin tahsili hakkında ise Sâlim Efendi “... tahsîl-i ma'ârif-i vefîr ve tekmîl-i avârif-i kesîrden”,16, Safâyî ise, “...evâil-i hâlinde tahsîl-i ma'ârif-i bisyâr ile asrun şu'arâsından olup" ${ }^{17}$ ifadelerine yer verir.

Yahyâ Nazîm'in tek eseri, Dîvân-ı Belâgat-unvân-ı Nazîm'idir. Divanının üçte ikisini na'tlar oluşturur. ${ }^{18}$ Divan şiirinde çok na’t yazan şairler arasında yer alan Nazîm, kasidelerinde Nef'î (ö. 1635), gazellerinde Neşatî (ö. 1674)'nin tesirleri görülen ve her iki şair yanında Fehîmi Kadîm (ö. 1648)'e de nazireler yazmış; divan edebiyatında şark1 türünün ilk örneklerini vermiştir. Bestekârlığının yanı sıra tiz ve etkili sesiyle dönemin önde gelen hânendelerinden olan Nazîm, devrin na'thanları ve dinî edebiyatın önemli şairleri arasında yer almış bir sanatkârdır. ${ }^{19}$ Bu hususta Bursalı Mehmed Tâhir Bey (ö. 1925): “Na't-gū-yı bî-nazîr olan bir şâir-i şehîrdir" ${ }^{20}$ ifadelerini kullanır. Tarihçi Atâ Bey (ö. 1883) ise Nazîm Yahya'yı, Na't-ĝ̂u

\footnotetext{
${ }^{13}$ Mustafa Uzun-Nuri Özcan, "Nazîm”, DİA C. 32, TDV Yay., İstanbul 2006, s. 452.

${ }^{14}$ Mustafa Uzun-Nuri Özcan, agm., s. 452.

${ }^{15}$ Pervin Çapan, Tezkire-i Safâŷ̀, AKM Başkanlığı Yayınları, Ankara 2005, s. 660.

${ }^{16}$ Adnan İnce, Tezkiretü 'ş-Şu'arâ, Sâlim Efendi”, AKM Başkanlığı Yayınları, Ankara 2005, s. 670.

${ }^{17}$ Pervin Çapan, age., s. 660.

${ }^{18}$ Şairin söz konusu külliyatı üzerine yapılmış çalışmalar için bk. Nevin Gümüş, Yahya Nazim Divanı I (̇́ncelemeMetin), Erciyes Üni., SBE, Yayımlanmamış Yüksek Lisans Tezi, Kayseri 1992: Aynur Çağliş̧lek, Yahya Nazim Divanı II (Inceleme-Metin), Erciyes Üni., SBE, Yayımlanmamış Yüksek Lisans Tezi, Kayseri 1991: Mehmet Şimşek, Yahya Nazim Divanı III (İnceleme-Metin), Erciyes Üni., SBE, Yayımlanmamış Yüksek Lisans Tezi, Kayseri 2007: Ahmet Kurban, Yahya Nazim Divanı IV (İnceleme-Metin), Erciyes Üni., SBE, Yayımlanmamış Yüksek Lisans Tezi, Kayseri 1992: Şaziye Kayhan Ertürk, Yahya Nazim Divanı V (İnceleme-Metin), Erciyes Üni., SBE, Yayımlanmamış Yüksek Lisans Tezi, Kayseri 1996.

${ }^{19}$ Mustafa Uzun-Nuri Özcan, agm., s. 453.

${ }^{20}$ Bursalı Mehmed Tâhir, Osmanlı Müellifleri I-II-III, (haz. Cemal Kurnaz-Mustafa Tatçı), Bizim Büro Yayınevi, C. II, Ankara 2009, s. 452.
} 
Nazîm Efendi olarak tanıtmış, çok sayıda na'tının olduğunu ayrıca ilim ve sanatını Enderun'da edindiğini kaydetmiştir. ${ }^{21}$

Edebiyat tarihimizde na't söyleyicilikle ün kazanmış olan Nazîm, lisanına hâkim, kalemine sahip ve divan edebiyatının icap ettirdiği bilgilere hakkıyla vâkıf bir üstad olduğundan, o devirde yetişmiş şairlerimizin önde gelenleri arasında görülür. ${ }^{22}$ Şeyhülislâm Es'ad Efendi'nin (ö. 1753) Atrabü'l-âsâr'ında ${ }^{23} 500$ 'den fazla beste, semaî ve şarkısı olduğunu söylediği Nazîm'in eserlerinden 300'e yakınının güftesi, güfte mecmualarında tespit edilmiştir. $^{24}$

\section{1. Üslûp ve Şekil Özellikleri}

Eser, çift kahramanlı aşk mesnevilerinde konu edinilen aşk hikâyelerine benzemesine rağmen hayalî ve olağanüstü herhangi bir olayın geçmediği, beşerî bir aşkın işlendiği gerçek bir hikâye görünümündedir. 160 beyitten meydana gelen mesnevi, sade bir üsluba sahiptir.

Klâsik mesnevilerin aksine Dâstân-ı Hecr ü Visâl'de "Besmele" kısmı bulunmamaktadır. Genel olarak ifade edilmek istenirse mesnevi, ana hatlarıyla üç ana bölümden meydana gelmektedir. Bunlar giriş, konunun işlendiği asıl bölüm ve hâtimedir. Eserin mukaddime kısmı tevhid (1-3. beyitler), münâcât (3-7. beyitler), na't (8-14. beyitler), sebeb-i te'lif (15-23. beyitler)'ten meydana gelmekte; asıl konunun yer aldığı âgâz-1 dâstân (24-145. beyitler) arasını kapsamakta ve son olarak hâtime (146-160. beyitler) kısmı gelmektedir. Şair, eser içerisinde 103 ile 109. beyitler arasını gazele; 113 ve 114. beyitleri ise rubaîye ayırmıştır.

Eser, aruz vezninin hafif bahrinden fe'ilâtün (fâ'ilâtün) mefâ'ilün fe'ilün (fa'lün) kalıbıyla yazılmıştır. Şairin eserde aruzu başarıyla kullandığı ifade edilebilir. Fakat, eserde yer alan birkaç beyitte vezin aksaklıkları göze çarpmaktadır. Söz konusu beyitler şu şekildedir: ${ }^{25}$

Zerreden de hakịir iken dil-i zār

Ṭaglarca henūz gușșası var

\footnotetext{
${ }^{21}$ Muhittin Eliaçık, Edebiyat Tarihimize Işık Tutan Bir Eser: Atâ Tarihinin 4-5. Ciltleri, İlmî Araştırmalar S. 20, İstanbul 2005, s. 76.

${ }^{22}$ Nazmi Özalp, Türk Mûsikîsi Tarihi, MEB Yayınları, C. 1, Ankara 1986, s. 169.

${ }^{23}$ Eser hakkında tafsilatlı bilgi için bk. Cem Behar, Şeyhülislâm'ın Müziği 18. Yüzyılda Osmanlı/Türk Musikisi ve Şeyhülislâm Es'ad Efendi'nin Atrabü'l-Âsâr'l, Yapı Kredi Yayınları, İstanbul 2010.

${ }^{24}$ Mustafa Uzun-Nuri Özcan, agm., s. 453.

${ }^{25}$ Veznin aksadığı mısralar italik gösterilmiştir.
} 
Nicedür ol garīiüñ ḥāli

'Aceb ol derd-mendüñ aḥvāli

Türk şiirinde imale, yabancı kelimelerin dile yerleşmeye başlaması ve şairlerin aruz ölçüsüne gittikçe alışmalarıyla birlikte giderek azalmaya başlamış, ama hiçbir zaman bütünüyle ortadan kalkmamıştır. Bütün çabalara rağmen yine de yüzyıllar boyu ve bütün şairlerde az ya da çok imaleli aruz uygulamaları görülmüştür. ${ }^{26}$ Nazîm'in mesnevisinde de bu uygulamanın yoğun olarak kullanıldığını görüyoruz. Eserde bunun örnekleri çoktur, biz burda birkaç tanesini vermekle yetiniyoruz:

Şādmān it beni ḥabībüm ile

Huastası oldıg்ım țabỉbüm ile

Yir içerken anıñla şām u seher

Bana dirken peder ben aña püser

Hālüme çeşm-i ‘ işve-bāzuñ içün

Naẓar eyle nigāh-1 nāzuñ içün

Mesnevilerde çoğunlukla kullanılan kafiye türü tam kafiyedir. Çoğu zaman zengin kafiye de (uzun ünlülerle yapılan kafiyeler: -ân, -ûn, -în gibi) kullanılmış olup, tam ve zengin kafiye "gür ve bol sesli" bir kafiyedir. ${ }^{27}$ Dâstân-ı Hecr ü Visâl' de de tam kafiye oranının diğer kafiye çeşitlerine nazaran daha yoğun kullanıldığını görüyoruz. Redifler çok defa divan şiirinin, Türkçe'nin ifade imkânlarını, söyleyiş hususiyetlerini denediği ve ana dilde kendisini bulduğu tarafıdır. Divan şiirinin redifleri Arapça ve Farsça kelimelerden çok Türk dilinin malzemesi üzerine kurulmuştur. ${ }^{28}$ Nazîm Yahya'nın mesnevisinde rediflerin önemli bir yeri vardır. Şair mesnevisinin 95 beytinde redife yer vermiştir. Bunların büyük kısmını Türkçe kelimeler teşkil etmektedir. Türkçe rediflerin bazıları şöyledir:

O Reșūlüñ çihār-yāri içün

Bezm-i ḩāșșında yār-1 gāāı içün

\footnotetext{
${ }^{26}$ Haluk İpekten, Nazım Şekilleri ve Aruz, Dergâh Yayınları, İstanbul 2010, s. 147.

${ }^{27}$ Cem Dilçin, Fuzulî’nin Bir Gazelinin Şerhi ve Yapısal Yönden İncelenmesi”, C. 9, S. 1, Türkoloji Degisi, s. 43-98.

${ }^{28}$ Ömer Faruk Akün, Divan Edebiyat,, İsam Yayınları, İstanbul 2013, s. 76.
} 
Cānı cānānuma mülāḳi ḳ̂l

Beni sermest anı sāḳi ḳıl

Evvel eylerken iltifāt baña

Hased eylerdi kā 'ināt baña

Nazîm Yahya mesnevisini sade bir dille kaleme almıștır. Nazîm, Sebk-i Hindî hareketinin tesirinde kalmış; bu tesir daha çok kendisini divanının muhtevasında göstermiştir. Derin hayaller, ince mazmunlar şairin şiirinde yer alan temel ögelerdir. Bununla beraber şairin Dâstân-ı Hecr ü Visâl'i üslûbunun akıcılığı ve yalın diliyle dikkat çekmektedir. Şairin şu beyti tamamen Türkçe kelimelerden meydana gelmektedir:

Bilmezem n'eyleyem nice ideyüm

Nereye başumı alup gideyüm

Kelime seçimi, ünlü ünsüz ilişkileri (aliterasyon/asonans), söz tekrarları, mısra tekrarları, vezin, kafiye, redif gibi paralellikler Divan şiirinde ahengi sağlayan en önemli unsurlardandır. ${ }^{29}$ Şair Nazîm, mesnevisinde söz konusu ses ve kelime tekrarlarına yer vererek üsluba canlılık kazandırmak istemiştir. Şair, böylece şiirde müzikaliteyi sağlamak ve ahenkli bir bütün ortaya koyma gayretindedir. Okuyucuya duygularının yoğunluğunu duyurma gayretinde olan şair, kulağa hoş gelen ses ve sözleri oldukça yoğun ve başarılı bir şekilde kullanmıştır. Bu hususta ön plana çıkan beyitler şöyledir:

Derd-i dilberde derde düşdi tenüm

Düşmenüm düşmeye o derde benüm

El-amān ey maḥabbet-i cānān

El-amān ey meşaḳḳat-i hicrān

Mahrem-i rāz u yār-1 ġārum idi

Kūşe-i ġamda ġam-güsārum idi

\footnotetext{
${ }^{29}$ Bahir Selçuk, Divan Şiirindeki Ses ve Ahenkle İlgili Sanatlara Genel Bir Bakış, Ulusal Eski Türk Edebiyatı Sempozyumu, Adıyaman 15-16 Mayıs 2008, s. 484.
} 
Cūy-veş sū-be-sū revān oldum

Cüst ü cū eyleyüp anı buldum

Eserde önemli bir yer tutan izafet kesreli tamlamalar hemen her beyitte görülür: (āl-i Aḥmed, vișāl-i Aḥmed, huāk-i pāy, çeşm-i ḥașret, āg̀ūş-1 cān, bāg̣-1 dünyā, pāy-1 'aḳl vs). Tamlamaların önemli bir yekûnunu da vasıf terkipleri oluşturur: (sehīi-ḳad, şūr-pezīr, teşne-leb, lāle-ḩad, 'işve-endiş̧e, vefā-pīşe, Țūbā-ḳıyām, sidre-ḩıām, meymenet-lüzūm vs). Mesnevinin dilinin sade olmasına binaen Sebk-i Hindî’nin de etkisiyle zincirleme isim tamlamaları eserde (şeref-i Hażret-i Muḥammed, naġme-perdāz-1 meclis-i gül, ḥabbe-i ḩāl-i rūy, derd-i miḥnet-i 'aşḳ, çeşme-sār-1 ' ālem-i ġayb, māh-1 bedr-i şām-1 ümīid, āfitāb-1 șubh-1 sa' īd, ġayret-i āhuvān-1 Çīn ü Ḩıțā, deyr-i hüsn-i melāḥat, şemşīr-i cān-te 'sīir-i āh, ālūde-i çirk-āb-1 töhmet, Kāc be-i kūy1 yār, meh-i bedr-i şām-1 āmāl, mihr-i raḩşān-1 șubḥ-1 iḳbāl, Kevṣer-nümūn-1 bāg̀ -1 behişt, naḩl-i bāĝ̣-1 cān, keyf-i cām-1 leb, mest-i șaḥbā-y1 'aşḳ, neyyir-i hüüsn-i bī-mis̄āl, rūḥ̂-1 pāk-i Muḥammed, kemāl-i żevḳ-i vișāl, ḥāl-i ḩaṣm-1 denī) 22 adettir.

Şair Nazîm, mesnevisinde 1 beytini mülemmâ beyit sayılabilecek Arapça kelimelerden meydana getirmiştir. Bununla birlikte şair, Arap edebiyatında kullanılan bir atasözüne de yer vermiş olur. Aynı doğrultuda şair “Dă̆ dağa kavuşmaz, insan insana kavuşur” ve “Hatasız kul olmaz" gibi Türk atasözlerini kullanarak irsal-i mesel sanatı yapar:

Ṭağ țag̉a ḳavuşmasa meșelā

Kavuşur ādem ādeme cānā

Çeşmüme sensiz oldı ḩ ${ }^{\circ} \bar{a} b$ ḥarām

'Acebā li'l-muḥibbi keyfe yenām ${ }^{30}$ (130)

Nola 'afv eyleseñ benüm günehüm

Kuul ḩațāsız olur mı pādişehüm

Eserde sevgili hayli başarılı bir şekilde tasvir edilmiştir, denebilir. Mesnevilerde önemli bir yer tutan tasvir hakkında Şentürk'ün tespitleri şu yöndedir: “Tasvirin amacı bir durumu veya imajı zihinde canlandırmak olduğundan, şair bu yolla sayfalarca anlatılabilecek bir sahneyi okuyucunun zihninde birkaç kelimeyle oluşturabilmektedir. Tasvirî anlatım, okuyucu veya dinleyiciyi çabuk etkileyen, verilmek istenen mesajı en kısa yoldan verip öğreten, hislendirip

\footnotetext{
${ }^{30}$ Seven nasıl uyur şaşarım!
} 
düşündüren bir metottur.”31 Dolayısıyla edebî tasvirde mecazî değişim genellikle teşbih, istiare, mecâz-1 mürsel, kinaye $v b$. edebî sanatlarla yapılmaktadır. $\mathrm{Bu}$ tasvirlerde kullanılan benzetmeler, mecazlar, tasvir edilen unsurları canlı ve neşeli göstermek amacına uygun olarak seçilmiştir. Şair sevgilisinin boyu için, servi ve fidan benzetmelerini kullanır:

Nā’il eyle vișāl-i Aḥmedüme

Serv-i āzāduma sehī-ḳadüme

Sözleri, ruhunun tercümanı, dili ise can bağışlayıcıdır:

Süḩanı tercümān-1 rūḥ-1 revān

Cān baġışlar ne söylese o zebān

Sevgilinin ağzı, gayb âleminin çeşmesi; beli ise k1l kadar ince ve kusursuzdur:

Deheni çeşme-sār-1 ‘ ālem-i gàbb

Mū miyānında ḳıl ḳadar yoḳ 'ayb

Saçları sünbül, yüzü taze bir menekșe; yanakları lâle, yüzü gül, göğsü nesrin (yaban gülü) gibidir:

Zülfi sünbül haț benefşe-i ter

Lāle-ḩad gül-' izāâr u nesrīn-ber

Yanakları âdeta mutlu sabahın doğan güneşi, alnı ise ümit akşamının dolunayıdır:

Cebhesi māh-1 bedr-i şām-1 ümīd

'Āriżı āfitāb-1 subh-1 sa`ìd

Çene çukuru sanki Zemzem suyunun çıktığı kuyu gibi, saçı da Kâbe'nin örtüsü gibi siyahtır:

Žeḳanı gūyiyā çeh-i Zemzem

Kisve zülfi cemāli Beyt-i Ḥarem

Sevgilinin kaşları çekilmiş iki yay gibi, gözlerinin okunun hedefi ise âşı̆̆ın can ve gönlüdür:

\footnotetext{
${ }^{31}$ A. Atilla Şentürk, XVI. Asra Kadar Anadolu Sahası Mesnevilerinde Edebî Tasvirler, Kitabevi Yayınları, İstanbul 2002, s. 21-22.
} 
Ebruvānī keşīide iki kemān

Nāvek-i çeşmine hedef dil ü cān

Sevgilinin elleri beş parmak, sanki güneşin pençelerini andırmaktadır:

Kef-i desti ile o beş barmak

Pençe-i āfitābdur el-ḥaḳ

Bedeni kâfûr mumuna naz eder, gömleği ise ona işve fanusudur:

Şem` -i kāfūra nāz ider bedeni

Aña fānūs-1 'işve pīreheni

Şair, mesnevisinin 103 ile 109. beyitleri arasında ise tekdüzeliği kırmak, üsluba akıcılık katmak, ayrıca sevgilisinin lutfuna layık olabilmek için bir gazel söyler. 7 beyitten müteşekkil, aruzun fâ'ilâtün fâ'ilâtün fâ'ilâtün fâ'ilün kalıbıyla yazılan gazelde şair, gazeli söylemeden önce bu durumu 102. beyitte okuyucuya haber verir:

Luṭ-1 yāre olınca erzānī

Eyledüm şevḳıle gazel-ḩ̌ānī

Gazelin habercisi olan bu beyitten sonra şair, söz konusu gazelde sevgilisinden kendisine merhamet etmesini ister. Âşık perişan hâldedir. Gönül mülküne sultan yaptı̆̆1 sevgilisi, şaire dönüp bakma lutfunu bile esirgemiştir artık. Şairin tek isteği sevgilisinin kendisine merhamet etmesidir. Nazîm bütün bunlar için sevgilisine niyaz etmekte; bu niyazını daha tesirli k1labilmek için de Hz. Peygamber'in mübarek şahsiyetini ve şefaatini dile getirmektedir:

Gözlerüm yaşını sil Aḥmed Muhammed 'aşḳına

Kadrümi bir kerre bil Aḥmed Muḥammed 'aşḳına

Bāde-i āl olmasun ruhsāruña reng-i ḥayā

Kendüñi itme hacil Aḥmed Muhammed 'aşḳıına

Serv-i dāmen-çīde ol seyl-i ‘ alāyıḳ̂dan ḥazer

Cūy-1 șāfî̀-veş çekil Aḥmed Muḥammed 'aşḳına 
El-ḥažer şemşīi-i cān-te 'sīir-i āhumdan benüm

Ġayr bezminden kesil Aḥmed Muhammed ‘aşḳına

Olmasun ālūde-i çirk-āb-1 töhmet dāmenüñ

Pāk-rū ol muttaṣıl Aḥmed Muḥammed 'aşḳ̣ına

Maḥfil-i vaṣlunda yansun tünd-bād-1 hicrile

Sönmesün ḳandīl-i dil Aḥmed Muhammed 'aşḳına

Merḥamet eyle Naẓīm-i zāra ạ̣vāl-i dilin

Söylemek lāzım degil Aḥmed Muhammed 'aşḳına

(103-109)

Şair sevgilisinin mahallesini görmek için gayret sarfetmektedir. Şair bu gayretini 112. beyit vasıtasıyla bir rubaîyi işaret ederek bizi haberdar etmektedir:

Nerede oldıġın maḥalle-i yār

Bu rubā‘ ìyle eyledüm iş̧ ār

Mesnevinin 113 ve 114. beyitlerini teşkil eden ve aruzun mef'ûlü mefầilün mefâ'ilün $f a$ ' kalıbıyla yazılan bu rubaîde şairin can gözü, sevgilinin ayrılı̆̆g ile onu arzu etmektedir. Sevgilinin yüzünün aks etmesiyle âşığın ağlayan gözü, Aynalı Çeşme’yi anımsatmaktadır:

\section{$\operatorname{Ruba} \bar{a}^{c} \bar{i}$}

Ḥayretde iken firāḳla dīde-i cān

'Arẓ itdi yine 'izāar-1 pākin cānān

'Aks eyleyeli cemāli ' aynile Naẓim

Āyīneli Çeşme oldı çeşm-i giryān (113-114)

Nazîm Yahya mesnevisinin hâtime kısmının son beytinde ise eserinin insanlar tarafından okunması için bir söz veya hikâye yazdığını, bu hikâyenin adını da Dâstân-ı Hecr ü Visâl koyduğunu ifade etmektedir. Dolayısıyla şair son beyitte eserinin ismini de zikretmiş olur:

'Āleme ḥasb ü ḥāl olup bu maḳāl

Didiler Dāstān-1 Hecr ü Vișāl 


\section{Tahkiyevî Özellikler ve Muhteva}

Klâsik Türk edebiyatı mesnevi yazım geleneğinde muhteva bakımından aşk konulu mesneviler genellikle âşık ile sevgili arasındaki aşkı anlatır (Leylâ vü Mecnûn, Yûsuf u Züleyhâ, Süheyl ü Nevbahâr). Dâstân-ı Hecr ü Visâl'de genel itibariyle Hecr (âşı)'in Visâl (sevgili)'e âşık olması, daha sonra Visâl'in Hecr'den ayrılması ve Hecr'in sevgilisine kavuşma yolunda çektiği sıkıntılar ve maceralar anlatılır.

Dâstân-ı Hecr ü Visâl mesnevisinin şahıs kadrosu zengin değildir. Kahramanlar Hecr, Visâl, Hecr'in yakın arkadaşı ve rakiplerdir. Fakat Hecr ve Visâl'in ismi -mesnevinin son beytinde eserin ismi hariç- hiç zikredilmez. Zira bu ikili arasındaki aşk hikâyesi hadiselerin zuhuru ve konunun gelişim çerçevesi içinde okuyucuya hissettirilir. Okuyucu bu yolla âşı̆̆ın "Nazîm" olduğunu anlar ki şair eserinde birkaç yerde mahlasını kullanıp; kendisine hitap ederek âşı̆̆ın, aşk serüveninde maruz kaldığı meşakkatleri dile getirmesi bu fikri destekler mahiyettedir.

Anlatma esasına dayalı bir metin niteliği taşıyan bu mesnevide, esas özne anlatıcının (ben anlatıcı, kahraman anlatıcı, tanık anlatıcı) varlığından söz etmek mümkündür.

$\mathrm{Bu}$ anlatıc1, kahramanlardan birisiyle aynileşir. Böylece metnin yapısı ve üslubu üzerinde "kahraman anlatıcı"nın kültür seviyesi, mizacı, dikkati ve içinde bulunduğu sosyolojik ve psikolojik şartlar etkili olur. $\mathrm{Bu}$ bakış açısından hareketle kaleme alınmış eserlerde "kahraman anlatıcı" daima ön plandadır. Eser boyunca, onun zaman içinde değişerek gelişmesi anlatılabileceği gibi, önce hayatının belirli bir dönemi nakledilir, bazı özellikleri belirtilir; sonra da çeşitli vesilelerle geçmiş dikkatlere sunulur. ${ }^{32} \mathrm{Bu}$ anlatıcı kendini roman kişisiyle özdeşleştirir; adeta onun bedenine girer ve onun diliyle konuşur. ${ }^{33}$ Hikâyenin ben anlatıcısı Nazîm'dir. Nazîm, âşıkla aynileşmiş, âşığın başından geçenleri ve aşk yolunda maruz kaldığı sıkıntıları kronolojik olarak okuyucuya olay örgüsü içinde vermiştir.

Dâstân-ı Hecr ü Visâl mesnevisinde mekân, çok net çizgilerle bilinen dış dünyaya ait coğrafyalar olarak verilmez. Mesnevi kahramanlarının ikamet ettiği herhangi bir mekân da yoktur. Hadiseler, yeri/konumu açıkça belirtilmeyen genel mekânlarda geçer. Anlatılarda, mekânın hususiyetleri üzerinde duran Tekin şu tespitlerde bulunuyor: "Mekân, anlatılarda sadece diş gerçekliğin (fizikî çevrenin) değil, büyük ölçüde iç gerçekliğin (moral gerçeğin)

\footnotetext{
${ }^{32}$ Şerif Aktaş, Anlatma Esasına Bağlı Edebî Metinlerin Tahlili, Kurgan Edebiyat, Ankara 2015, s. 83.

${ }^{33}$ Nurullah Çetin, Roman Çözümleme Yöntemi, Öncü Kitap, Ankara 2009, s. 106.
} 
ortaya konulmasında, yansıtılmasında araç olarak kullanılır. Bu bakımdan mekân unsuru, kişilerin kimliğini yönlendiren bir etken olarak kullanıldığını bilmek gerekir.”34 Örneğin eserde yer alan Kâ'be motifi âşı̆̆ın sevgilisinin mahallesini temsil etmekte, divan şiirinin terennüm ettiği söz konusu bu Kâ’be motifi sevgilinin ikametgâhıyla bütünleşmektedir:

Kāc be-i kūy-1 yāre țālib idüm

Görmege ol makāāmı rāg̀ıb idüm

Ayrıca eserde yer alan bu ve buna benzer mekânsal ögeler daha çok hayalî olup, teşbih ve tasvir amaçlı kullanılmıştır. Şair, en ufak bir çöp parçasının gözüne Kaf dağı gibi göründüğünü, sevgilinin mahallesinin ise Kâ'be'yi andırdığını ifade eder. Yine şair, sevgilinin çenesini Zemzem kuyusuna; yüzünü Beyt-i Harem'e teşbih eder. Son olarak ise sevgilinin misk kokulu beni, Çin ve Hita ülkesinde yaşayan ceylanların gayretine benzetilmiştir:

Cebel-i Ḳāf idi hemān kef-i huas

Baña 'Anḳā gelürdi per-i meges

Zekạanı gūyiyā çeh-i Zemzem

Kisve zülfi cemāli Beyt-i Harem

Ḩāl-i müşgīni ḥabbetü’s-sevdā

Ġayret-i āhuvān-1 Çīn ü Ḩiṭā

Şair, tevhid, münâcât ve na’t bölümlerinden sonra sebeb-i te'lif kısmında dünyada gam ve kederinin olmadığını, güzel günler geçirdiğini, güzellerin kendi sohbet ve ülfetine meyilli olduğunu, Kaf dağı ve Anka kuşunun gözünde bir değeri olmadığını söyler. Belli bir mekânı yoktur; gönlü nereyi arzu ederse orada ikamet eder. Gündüzünün ve gecesinin bayram, bahtının açık olduğunu, kısacası vaktini mutlu bir şekilde geçirdiğini dile getirir:

Bir zamān ben de bāg̀g-1 dünyāda

Her țaraf geşt iderdüm āzāde

Hūular țālib idi ülfetüme

Dilberān rāġıb idi șoḥbetüme

\footnotetext{
${ }^{34}$ Mehmet Tekin, Roman Sanatı, Hece Yayınları, Ankara 2007, s. 142.
} 
Çarh yanumda berg-i tere idi

Gözüme āfitāb zerre idi

Cebel-i Ḳāf idi hemān kef-i ḩas

Baña 'Anḳā gelürdi per-i meges

Ġamdan olmışdı cān u dil 'ārī

Germ idi ževḳ u şevḳ bāzārı

Pür-neşāṭ idi meclis-i țarabum

'Iyd u Kadr olmışıdı rūz u şebüm

Meskenüm bāg u rāg idi evvel

Baña tag üsti bāg idi evvel

Çarh-1 kec-rev degildi nā-hemvār

Ṭālic üm yāver idi baḩtum yār

'Ayş u ' işretde şād u hurrem iken

Bezm-i ‘ ālemde böyle bī-ġam iken (32)

Fakat şair, ansızın aşk belasına tutulmuş; dalgalanıp coşan bir deniz iken sessizliğe bürünmüştür. Aşka düşmeyi, kaza ve belaya giriftar olmak şeklinde telakki eden şair, aşk fitnesinin can ve gönül mülkünü içine aldığını, ayrıca aşk derdinin canına yettiğini, aşkın heybetinin kendi sesini, soluğunu kestiğini ifade eder:

Nāgehān bir belāya duş oldum

Yem-i pür-cūş iken ḩamūş oldum

Dil-i zārı belāya ug̣ratdum

Ne belāya każāya ugiratdum

Mülk-i cān u dil oldı pür-teşvīr

Fitne-i 'aşk itdi şūr-pežīr 
Cāna kār itdi derd-i miḥnet-i ' aşk

Beni dem-beste ḳıldı heybet-i 'aşḳ (39)

Aşka tutulan şair, âlemi tesir altına alan aşk derdinden yakınmakta; kendisinin düştüğü bu derde düşmanının düşmesini bile istememektedir. O güzeller şahının müptelası şair, aşk dergâhının dilencisi konumuna düşmüştür. Sevgili, şair için saçlarının gamıyla yanıp yakınılan bir Leyla, dudaklarının ayrılığıyla susuzluğu hissedilen bir Şirin'dir:

Āh ey derd-i ‘ aşḳ-1 ‘ ālem-gīr

Ki ider şīi gürbe gürbeyi şīr

Derd-i dilberde derde düşdi tenüm

Düşmenüm düşmeye o derde benüm

Bir şeh-i hüsne mübtelā oldum

Dergeh-i ‘ aşḳına gedā oldum

Ġam-1 zülfiyle Leylī bir miskīn

Hecr-i la' liyle teşne-leb Şīīin

Hecr'in, sevgilisine duyduğu derin sevgi ve muhabbetin karşılığında Visâl de âşığına iltifatlar etmekte, ağladığı zaman ona merhamet göstermektedir. Visâl, âşığını tebessümüyle mutlu eder, Hecr'in canına can katar. Fakat rakipler bu durumu kıskanmaktadır. Sevgili hem güzel ahlakıyla hem de güzelliğiyle meşhurdur, öyle ki lutfunu âşığından esirgememektedir. Sevgilinin hayal edilebilecek olumsuz taraflarına karşılık o, âşı̆̆ın canı, yaşama vesilesidir:

Evvel eylerken iltifāt baña

Hased eylerdi kā'ināt baña

Girye itsem teraḥhum eylerdi

Her nigehde tebessüm eylerdi

Hüsnile hulḳıla olup meşhūr

Beni itmişdi luṭfına mag̉rūr 
Bilmiş iken o şūh-1 mekkārı

Cānumuñ cānı 'ömrümüñ varı

Şair, sevgilisi ile bahtiyar iken rakipler bu durumdan rahatsız olurlar, aralarında ittifak ederek bu iki sevgiliyi birbirinden ayırmak isterler. Rakiplerden birinin âşı̆̆ın yakın dostu olduğunu, sabah akşam âşıkla birlikte olduklarını, hatta aralarında baba-oğul yakınlığının bulunduğunu anlıyoruz. O rakip, âşı̆̆ı sevgilisinden ayırmış, gönlüne ayrılık ateşini düşürmüştür. Rakibi "hasûd” (çok kıskanç) olarak vasıflandıran ve İblis’e teşbih eden şair, ömrünün kısa olması ve iki cihanda hiçbir muradına ermemesi yönünde beddualarda bulunur:

Ruḳebā ḥayf ittifāḳ itmiş

Haberüm yogiiken nifāḳ itmiş

İçlerinden o demde bir bī-dīn

Yogiken beynümüzde kibr ile kīn

Yir içerken anıñla şām u seḥer

Baña dirken peder ben aña püser

Sebeb oldı firāḳ-1 cānuma

Dil ü cānumda dāg̀g-1 ḥicrāna

O melekden beni ayırdı ḥasūd

Ola İblīs-i ġūl-veş merdūd

' Ömri nāḳıṣ ġamı ziyād olsun

İki ‘ ālemde nā-murād olsun

Şair, sonunda sevgilisinden ayrı düşmüş, ayrılık derdi canına işlemiştir. Bu dert, şairi toplum içinde gülünecek bir hâle getirmiş, gözleri kanlı yaşlar dökmektedir. O derece ki şair, sevgilisinin yüzünü suyun aksinde veya rüyasında görebilmeyi arzu etmektedir. Âşık ne yapacağını bilememekte, garip ve çaresiz kalmıştır:

Yārdan 'āḳıbet cüdā düşdüm

Derd-i hicrāna mübtelā düşdüm 
Cānuma geçdi firḳat-i cānān

Bağrumı yaḳdı āteş-i hicrān

Derd-i devri esīr-i künc itdi

Beni ‘ ālemlere gülünc itdi

Ḥasretiyle gözüm döker ḳan yaş

Görmeyeydüm bu demleri ey kāş

'Aksine ḳā'il oldum āb içre

Yāri görsem n'olaydı ḩॅāb içre

Bilmezem n'eyleyem nice ideyüm

Nereye başumı alup gideyüm

$\mathrm{Bu}$ çaresizlik içinde âşık gam köşesinde ağlamakta, hasret ateşi göğsünü dağlamaktadır. Âşı̆̆ın bu durumundan haberdar olan bir sırdaşı, sohbet arkadaşı, yalnızlık köşesinde gam ve kederini paylaştığg bir dostu vardır. Arkadaşı, âşığın bu hâlini gider sevgilisine arz eder. Âşığın kendisine can u gönülden bağlı olduğunu, uygun görürse tekrar lutfuna mazhar olmasını beyan eder. Ayrıca sevgilisinden insaflı davranıp âşı̆̆a merhamet etmesini talep eder:

Künc-i gamda demādem ag̉lar iken

Nār-1 ḥașretle sīne dag̉lar iken

Var idi bir ḩabīi-i ạ̣vālüm

Aña ma` lūm idi benüm ḥālüm

Maḥrem-i rāz u yār-1 gāarum idi

Kūşe-i ġamda ġam-güsārum idi

Varup aḥvālümi dimiş yāre

O cefā-cūya ol sitemkāre

Cān u dilden muhibb-i șādıḳdur

Maẓhar-1 luṭuñ olsa lāyıḳdur 
Șadme-i āhı ‘ālemi yı̣̣dı

Nālesi çaḳ feleklere çıḳdı

Saña inșāf virsün Allāhum

Ġarażuñ cevr ise yeter şāhum

Sevgili, âşığın arkadaşını dinler ve alnını buruşturarak "kendisine sadık bir köleyim” diyen âşığın bir daha kendisini anmamasını ister; kulu olsa da onu serbest bıraktığını, âşığa da aynen böyle söylemesini ifade eder. Sevgili naz ve işvesine devam etmiş; eziyet maksadıyla çok kelâm söylemiştir. En sonunda âşığa selam ederek arkadaşını göndermiştir:

Gūş idüp sözlerin șūret-i çīn

Gösterüp nāzikāne çīn-i cebīn

İtmesün ' āşıḳum diyü beni yād

Kulum olursa eyledüm āzād

Böyle söyle dimiş o hem-rāza

Başlamış nice şive vü nāza

Gāh nāz u gehī niyāz olmış

Arada çoḳ niyāz u nāz olmış

Kạṣd-1 cevrile çoḳ kelām itmiş

Āhirinde veli selām itmiş

Arkadaşı bu haberle âşığın yanına gelir, dertli gönlünü neşelendirmek ister. Kırılan kalbini yine eskisi gibi şâd etmek ve ayrılık duygusunu artık gönlünden çıkarmasını söyler. Zira âşık perişan hâlde, acı çekmekte ve bu duruma son verme gayreti içerisindedir:

Dimiş ol gusșṣa-mendi şād ideyüm

Yine vașlımla ber-murād ideyüm (96)

Kalbini ġamdan eyleyüp āzād

İdeyüm ḩāṭr-1 ḥazīnini şād 
Nicedür ol garīiüñ̃ ḥāli

'Aceb ol derd-mendüñ aḥvāli

İntiz̄ārı irişdi pāyāna

Eylesün el-vedā‘ hicrāna

Âşık, arkadaşından müjdeyi alır ve sevgilisi için iyi dileklerde bulunmak ister. Âşık, sevgilisinin boyunun servi gibi yüksek; ömrünün saçları gibi uzun olmasını diler. Sevgilinin lutfuna tekrar mazhar olan âşık, bu şevk ile bir de gazel terennüm eder:

Bu hyaberle o dilber-i țannāz

Eylemiş bendesin yine mümtāz

Kāmeti serv-i ser-efrāz olsun

' Ömri zülfi gibi dırāz olsun

Luṭf-1 yāre olınca erzān $\bar{i}$

Eyledüm şevḳıle gazel-ḩ̌ān̄i

Gazel

Gözlerüm yaşını sil Aḥmed Muhammed 'aşḳına

Kadrümi bir kerre bil Aḥmed Muḥammed 'aşḳına

Bāde-i āl olmasun ruhsāruña reng-i ḥayā

Kendüñi itme hyacil Aḥmed Muhammed 'aşḳıına

Serv-i dāmen-çīde ol seyl-i ‘ alāyıḳdan ḥazer

Cūy-1 șāfí-veş çekil Aḥmed Muḥammed 'aşḳına

El-ḥažer şemşīr-i cān-te 'sīir-i āhumdan benüm

Ġayr bezminden kesil Aḥmed Muḥammed ‘aşḳına

Olmasun ālūde-i çirk-āb-1 töhmet dāmenüñ

Pāk-rū ol muttașıl Aḥmed Muḥammed 'aşḳıına 
Maḥfil-i vașlunda yansun tünd-bād-1 hecr ile

Sönmesün ḳandīl-i dil Aḥmed Muḥammed 'aşḳına

Merḥamet eyle Naẓim-i zāra aḥvāl-i dilin

Söylemek lāzım degil Aḥmed Muḥammed ‘aşḳına (103-109)

Edebiyatta aşk, sevgi, güzellik, kavuşma vs. imajlar için Kâ'be adı çokça anılır. Özellikle tenasüp yoluyla çok kullanılır. Sevgilinin yüzü ve mahallesi Kâ'be’ye benzetilir. Âşık orada dolaşmakla Kâ'be'yi tavaf etmiş olur. ${ }^{35}$ Şair Nazîm de bu duygular içinde sevgilisine tekrar kavuşmak için onun mahallesine (Kâ’be) gitmek ve onu görmek ister. Sevgilisinin mahalllesine su gibi akan şair, onu bulma gayretindedir. Şair, sevdiğinin mahallesinin nerede olduğunu bir rubaî ile bildirmekte; böylece onun Aynalı Çeşme'de oturduğunu ima etmektedir:

Kā‘ be-i kūy-1 yāre țālib idüm

Görmege ol maḳāmı rāğıb idüm

Cūy-veş sū-be-sū revān oldum

Cüst ü cū eyleyüp anı buldum

Nerede oldıg̀ın maḥalle-i yār

Bu rubā``ìle eyledüm iş` ār

\section{$\operatorname{Rub} \bar{a}^{c} \bar{i}$}

Ḥayretde iken firāḳla dīde-i cān

'Arẓ itdi yine 'izāar-1 pākin cānān

'Aks eyleyeli cemāli ‘ aynile Naẓīm

Āyīneli Çeşme oldı çeşm-i giryān (113-114)

Sevgilinin mahallesine erişen şair, burada ona medhiyeler dizmektedir. Şair, vecd hâli içinde kendinden geçmiştir. Sevgili, âşı̆̆ın nazarında arzularının akşamı, dolunayı; saadet sabahının parlayan güneşidir. Cennet içerisinde boyu Tûbâ, yürüyüşü ise Sidre ağacı gibidir. Dudakları cennet bağının kevseri, yanakları parlak bir gül, yine boyu gönül bağının fidanıdır. Âşık, sevgilisinden kendisini kavuşma şarabıyla mest edip keder sarhoşunu ayıltmasını ister.

\footnotetext{
${ }^{35}$ İskender Pala, Ansiklopedik Divan Şiiri Sözlüğ̈̈, Kap1 Yayınları, İstanbul 2012, s. 245.
} 
Çünkü şairi, aşka rüsva eden ve aşk kadehine düşüren yine sevgilidir. Sevgilisiz, âşığın gözüne uyku girmemekte; seven insanın da hasret acısı çekerken nasıl uyuduğuna da şaşırmaktadır. Can u gönülden, bütün samimiyeti ile kendisine hitap eden âşık, riyasız olarak sevgilisinin sadık bir kölesidir:

Ey meh-i bedr-i şām-1 āmālüm

Mihr-i rahşān-1 șubḥ-1 iḳbālüm

Ey behişt-i melāḥat içre müdām

Kadi Ṭūbā-ḳıām u Sidre-hırām

Ey cinān-1 cemāle hụ̂r-1 sirişt

Lebi Kevșer-nümūn-1 bāg̀-1 behişt (117)

Ruhlaruñ verd-i bī-ḥazānumdur

Kāāmetüñ nahll-i bāg̀-1 cānumdur

Bāde-i vuṣlatuñla mest eyle

Bu humār-1 ġamı şikest eyle

Beni rüsvā-yı ‘ aşk iden sensün

Mest-i șaḥbā-yı ‘ aşḳ iden sensün

Çeşmüme sensiz oldı ḩ̌āb ḥarām

'Acebā li'l-muhịbbi keyfe yenām ${ }^{36}(130)$

Cān u dilden Nazịm-i ' āşıḳuñam

Bī-riyā bir muhịbb-i șādıḳuñam

Âşı, sevgilinin verdiği bunca cevr ü cefanın sebebini merak eder. Suçunu öğrenmek ve ondan bin utanç içinde özür dilemek ister. Sevgilisinin kendisini affetmesini ve ona eskisi gibi âşık olduğunu söylemeyi diler. Çünkü bu gönül onu sevmekle kâfir olmamıştır ya... Ayrıca kin ve nefret tutan kişilerin kalbinde din duygusu olmaz. İnanan insanın kalbinde de kibir ve kin

\footnotetext{
${ }^{36}$ Seven nasıl uyur şaşarım!
} 
gibi olumsuz huylar bulunmaz. Âşık, sevgilisinden suçunu bağışlamasını -eğer bir suç işlemişse- neticede kul olanın da suç işleyebileceğini bütün samimi duyguları ile dile getirmektedir:

Baña bildür günāhumı bileyüm

'Özrümi biñ hicāb ile diyeyüm

$\mathrm{Bu}$ güneh besdür ol dil-figāre

Ki saña 'āşıkum diye yāre

Ey büt-i deyr-i 'işve el-hạaș1

Seni sevdiyse kāfir olmadı dil

Ehl-i buġż u garazda dīn olmaz

Ḳalb-i mü’minde kibr ü kīn olmaz (141)

N'ola 'afv eyleseñ benüm günehüm

Kul hatāāsı olur mı pādişehüm

Âşık aslında kendisine iftira atıldığını, bu iftira karşısında güzeller şahının kendisini affetmesi gerektiğini söyler. Çünkü sevgili, rakiplerin sözüne itimat etmiş; âşı̆̆ının yüzüne dahi bakmamıştır. Bundan dolayı âşık, sevgilinin sohbetinden hep mahrum kalmış; kendisine mazlum, sevgilisine de zalim sıfatını uygun görmüștür:

Saña lāyık mı ey şeh-i hūūān

Huașm-1 dūn eyleye baña bühtān

Í timād eyleyüp anuñ sözine

Baḳmaz olduñ bu bendenüñ yüzine(144)

Șoḥbetüñden senüñ olam mahrūm

Saña zālim dine baña maẓlūm

Âşık, eserinin hâtime bölümünde Hz. Peygamber'in mübarek ruhuna salât u selâm getirir. Şair, bu mahallede sevgilisini görmüş; eli ve eteğine yüzünü sürmüştür. Sonunda ise düşmanları âşığı sevgilisinden ayırmıștır. Fakat șair muradına erememiş biri olarak, doğru ve 
yalanların ortaya çıkmasıyla da son derece mutludur. O nifak ehlinin yüzü kara, kendisinin ise alnı açık, yüzü paktır. Düşmanlarının hâli mahv olmuş, talihleri ise tersine dönmüştür:

Beni senden ayırmış idi ‘ adū

Başına geldi āhir ey meh-rū

Nice dem gerçi nā-murād oldum

Ṣıdḳ u kižbüm bilindi şād oldum

Oldılar rū-siyāh ehl-i nifāḳ

Oldı alnum açı̣ benüm yüzüm ạ̣ (155)

Ḥāl-i hașm-ı denī tebāh oldı

Bahtı ber-geşte kārı āh oldı

Yine hâtime bölümünde şair, bozguncu rakiplerin kendi ettiklerini bulduklarını, beter bir hâle geldiklerini ifade etmektedir. Âşık, kendisine yapılan kötülüklerin müsebbibini de tanımış, rakibin kendi kazdığı kuyuya kendisinin düştüğünü ifade etmiştir. Şair söz konusu hikâyesinin ismini Dâstân-ı Hecr ü Visâl koymuş, insanların okuması ve birbirleriyle hâlleşmeleri için de eserin bir vesile aracı olduğunu kaydetmiştir:

Baña Ḥaḳ ‘āḳıbet o nā-merdi

Nice istersem öyle gösterdi

Yolına geldi ugiradı āha

Kendüsi düşdi ḳazduġı çāha

‘ Āleme hasb ü hāl olup bu maḳāl

Didiler Dāstān-1 Hecr ü Viṣāl

\section{Sonuç}

Nazîm Yahya'nın kaleme aldığı Dâstân-ı Hecr $\ddot{u}$ Visâl, şairin 1668 tarihinde tamamladığı birinci divanında yer almaktadır. 160 beyitten meydana gelen mesnevi, âşıkane konulu bir sergüzeşttir. Eser, genel manada üç ana (giriş-asıl konunun işlendiği bölüm-hâtime) bölümden meydana gelmekte; klâsik mesnevi hususiyetlerini (tevhid-münâcât-na't-sebeb-i 
te'lif, âgâz-1 dâstân-hâtime) içerisinde barındırmaktadır. Ayrıca şair metin içinde bir gazel ve rubaîye yer vererek; tekdüzeliği kırmak, üslûba akıcılık ve heyecan kazandırmak istemiştir.

Dâstân-ı Hecr ü Visâl aşk temalı bir mesnevidir. Konusunu âşık ile sevgilinin arasındaki hikâyeden alır. Birbirlerine derin ve samimi bir muhabbet duyan iki âşık, aşkın verdiği neşe ile mutlu bir hayat sürmekte iken rakiplerin türlü oyunları neticesinde araları bozulmuştur. Aralarının bozulması sonucu yaşanan hadiseler mesnevinin seyrini teşkil etmiş, tahkiyevî ve tasvirî anlatımın kattığı canlı ve renkli üslûp vesilesiyle edebî bir metin değerini kazanmıştır. Metinde sevgilinin âşığı affettiği veya onunla tekrar bir araya geldiğine dair herhangi bir kaydın da bulunmaması, eserin dikkat çeken bir başka yönüdür.

Hikâye, okura özne anlatıcının (ben anlatıcı) ağzından nakledilmiştir. Bu durumda âşı̆̆ın asıl kimliği şairle birleşmiş, yaşananların Nazîm'in başından geçtiği anlaşılmıştır. Sade bir üslûpla kaleme alınan eser, yazıldığı dönemin başarılı mesnevileri arasında sayılabilir. Yer yer mahallî unsurların da görüldüğü eserde, dönemin dil zevki ve estetik anlayışı müşahede edilmektedir. Şairin yegâne eseri Divan-ı Belâgat-unvân-ı Nazîm’i incelenip, tahlile tabi tutulduğunda eserin edebiyat tarihi içindeki yerinin tespit edilmesinde önemli katkılar sağlayacağı da açıktır.

\section{DĀSTĀN-I HİCR Ü VISṢĀL}

fe'ilâtün / mefâ'ilün / fe'ilün

Ey mu'in u zahīr olan Allah

' Ācize dest-gīr olan Allah

1. Sen mu'in ü zahīiüm ol yā Rabb

' Ācizem dest-gīiüm ol yā Rabb

2. Şeref-i Ḥażret-i Muḥammed içün

Ṣaḥb u evlād u āl-i Aḥmed içün

3. O ḥabībüñ cemāli hüurmetine

Saña ḳurb u vișāli hürmetine

4. O Reșūlüñ çihār-yāri içün

Bezm-i ḩāșṣında yār-1 gāār içün 
5. Hasan ile Hüseyn hürrmetine

Veled ü vālideyn hürmetine

6. Baña luṭf it murād u makṣ̂̄dum

Ey Kerīm ü Raḥim ma` būdum

7. Şādmān it beni habỉbüm ile

Hastası oldıġım țabībüm ile

8. Cānı cānānuma mülāḳi ḳ̂l

Beni sermest anı sāḳi ḳ̂l

9. Nầil eyle viṣāl-i Aḥmedüme

Serv-i āzāduma sehī-kadüme

10. Yine bir kez cemālini göreyüm

Yüzümi hāāk-i pāyiñe süreyüm

11. Gelsün āg̀ūş-1 cāna cānānum

Yerine 'avdet eylesün cānum

12. Beni böyle garīib ü āvāre

Komasun firḳatiyle bī-çāre

13. Yoldadur çeşm-i hașretüm yā Rabb

Kalmadı șabra țāḳatum Yā Rabb

14. Bir zamān ben de bāg̀-1 dünyāda

Her taraf geșt iderdüm āzāde

15. Pāy-1 ' aḳlumda yog̀idi ḳaydum

Şāhbāzān-1 nāz idi șaydum

16. Șubḥum olmışdı gün gibi tābān

Şebüm eylerdi meh-veşān rahşān

17. Hūūblar țālib idi ülfetüme

Dilberān rāg̀ıb idi șoḥbetüme

18. Kanda bir gonce ola bülbül idüm

Naġme-perdāz-1 meclis-i gül idüm 
19. Leb-i dilber șunardı ma` cūnum

Habbe-i ḩāl-i rūyı efyūnum

20. Germ-bāzār idüm şarāb gibi

Ḩāne-ber-dūş idüm hạabāb gibi

21. Dembedem mecma` -1 hüner-mendān

Baña olmışdı mekteb-i 'irfān

22. Hậ̣̣̂lı bī-niyāz idüm meselā

Nāz-1 dehre iderdüm istig̉nā

23. Bì-gam-1 rūzgār idi nāmum

Kāmrāne geçerdi eyyāmum

24. Çarh yanumda berg-i tere idi

Gözüme āfitāb zerre idi

25. Naẓarumda felek degildi kelek

'Aynuma gelmez idi hūr u melek

26. Cebel-i Kāâf $\mathrm{f}^{37}$ idi hemān kef-i hyas

Baña ${ }^{c} A n k \bar{a}^{38}$ gelürdi per-i meges

27. Ġamdan olmışdı cān u dil ' ārī

Germ idi ževḳ u şevḳ bāzārı

28. Pür-neşāt idi meclis-i tarabum

'Iyd u Kadr olmış idi rūz u şebüm

29. Meskenüm bāg u rāg idi evvel

Baña tạg üsti bāg idi evvel

30. Çarh-ı kec-rev degildi nā-hemvār

Ṭālic üm yāver idi bahtum yār

\footnotetext{
37 “İptidaî kültürlerden itibaren gelişim süreci izlenebilen bu motif İslâm kültüründe Kafdağı adıyla bilinir. Kur’an'da bir bilgi bulunmamasına rağmen tefsir, tarih ve edebiyat literatüründe bu konu genişçe işlenmiştir. Kafdağı'nın mahiyeti tartışmalıdır. Bazı rivayetlerde somut gerçekliği, coğrafî varlığı olan bir dağ, bazılarında soyut, mistik bir sembol olarak kabul edilmektedir." $b k$. (Demirci, 2001, s. 144)

38 "Ankâ, divan edebiyatının manzum ve mensur metinlerinde müsbet özellikleriyle zikredildiğinde renkli tüyleri ile bir cennet kuşudur. Kafdağı'nda yaşaması, yükseklerden uçması ve kolay avlanamayışı gibi özellikleri sebebiyle ulaşılması çok zor durumları ifade etmek için kullanılır." bk. (Pala, 1991, s. 201)
} 
31. 'Ayş u ' işretde şād u hưrrem iken

Bezm-i ‘ālemde böyle bì-gam iken

32. Nāgehān bir belāya duş oldum

Yem-i pür-cūş iken ḩamūş oldum

33. Dil-i zārı belāya ug̣ratdum

Ne belāya każāya ugiratdum

34. Şāh-1 ' aşḳa dil oldı dest-āvīz

Mihre gūyā ki zerre-i nāçīz

35. Zerreden de hạạīr iken dil-i zār

Ṭag̉larca henūz guș̦sası var ${ }^{39}$

36. Mülk-i cān ü dil oldı pür-teşvīr

Fitne-i 'aşk itdi şūr-pezīir

37. Sipeh-i 'aşḳa pāymāl oldum

Kevkeb-i mevkibiyle lāl oldum

38. Cāna kār itdi derd-i miḥnet-i 'aşk

Beni dem-beste ḳıldı heybet-i 'aşk

39. Āh ey derd-i 'aşk-1 'àlem-gīr

Ki ider şīi gürbe gürbeyi şīr

40. Göñlüme derd-i 'aş̣ maḥremdür

Gözüme hūn-1 eșk hem-demdür

41. Derd-i dilberde derde düşdi tenüm

Düşmenüm düşmeye o derde benüm

42. Bir șeh-i hüsne mübtelā oldum

Dergeh-i ' aşḳına gedā oldum

43. Mihr-i enver ḩacīl cemālinden

Māh şermende rūy-1 ālinden

44. Ġam-1 zülfiyle Leylī bir miskīn

Hecr-i lac liyle teşne-leb Şīin

\footnotetext{
${ }^{39} \mathrm{Bu}$ mısrada vezin aksamaktadır.
} 
45. Lebi ' ayniyle çeşme-i ḥayvān

Bir içim șudur ol şeh-i huūbān

46. Deheninde gören o dendānı

Șadefinde güher șanur anı

47. Sühanın tercümān-ı rūḥ-ı revān

Cān baġışlar ne söylese o zebān

48. Deheni çeşme-sār-1 ' ālem-i gāāyb

Mūmiyānında ḳıl ḳadar yọ̣ ‘ayb

49. Zülfi sünbül ḩațı benefşe-i ter

Lāle-ḩad gül-c izāār u nesrīn-ber

50. Cebhesi māh-1 bedr-i şām-1 ümīd

' Ārıżi āfitāb-1 șubḥ-1 sa' ìd

51. Zeḳanı gūyiyā çeh-i Zemzem ${ }^{40}$

Kisve zülfi cemāli Beyt-i Ḥarem

52. Ebruvānı keşīe iki kemān

Nāvek-i çeşmine hedef dil ü cān

53. Ḩāl-i müşgīni ḥabbetü's-sevdā

Ġayret-i āhuvān-1 Ç̄inn ${ }^{41}$ ü Hut $\operatorname{ạ}^{42}$

54. Kef-i desti ile o beş barmak

Pençe-i āfitābdur el-ḥak

55. Kadi serv ü cinān-1 hüsn ü behā

Sāc idi şāh-1 Sidre vü Ṭūbā

56. Şem ${ }^{c}-i$ kāfūra nāz ider bedeni

Aña fānūs-1 'işve pīreheni

57. Deyr-i hüusn-i melāḥat içre müdām

Kāfir-i zülfí düşmen-i İslām

\footnotetext{
40 "Kâbe yakınlarında kuyudan çıkan, müslümanların büyük değer verdiği su.” bk. (Küçükaşcı, 2013, s. 242)

41 "Edebiyatta Çin, resim sanatının merkezi olarak işlenir. Ayrıca Çin ülkesinde Türkler ve özellikle Hıtâ, Huten, Maçin diyarının halkıyla Çiğil güzellerinin de bulunuşu kelimeye geniş kullanım sahası sağlamıştır. Bu ilişkiden yola çıkılarak sevgilinin misk kokulu saçı anılır. Çünkü misk orada bulunur.” bk. (Pala, 2012, s. 103)

42 "Çin'in kuzeyi ile Türkistan topraklarına verilen ad. Hatâ ve Huten şekilleriyle de kullanılan bu kelime özellikle ahu ve misk ile birlikte kullanılır." bk. (Pala, 2012, s. 197)
} 
58. Pīşesi nāz u 'işve-endiş̧e

Hem cefākār u hem vefā-piş̧e

59. Gerçi maḥbūb-1 şūh u şengüldür

Āşināsı hezār bir güldür

60. Çekilür yār içün ġam-1 ag̉yār

Huārsız gül bulınmaz ey dil-i zār

61. Böyledür rūzgāruñ aḥvāli

Ki degil nūş nişsen ḩāli

62. Evvel eylerken iltifăt baña

Hased eylerdi kā'ināt baña

63. Girye itsem teraḥhum eylerdi

Her nigehde tebessüm eylerdi

64. Hüsn ile hulk ıle olup meşhūr

Beni itmişdi luțfına mag̉rūr

65. Bilmiş iken o şūh్̄-1 mekkārı

Cānumuñ cānı `ömrümüñ varı

66. Rukebā hayf ittifāk itmiş

Ḥaberüm yogiken nifāḳ itmiş

67. İçlerinden o demde bir bī-dīn

Yoġiken beynümüzde kibr ile kīn

68. Yir içerken anıñla şām u seher

Baña dirken peder ben aña püser

69. Sebeb oldı firāḳ-ı cānuma

Dil ü cānumda dā $\dot{g}-1$ hịcrāna

70. O melekden beni ayırdı hasūd

Ola İblīs-i gūul-veş merdūd

71. 'Ömri nāḳıṣ gamı ziyād olsun

İki ‘ālemde nā-murād olsun 
72. Yārdan ' āḳıbet cüdā düşdüm

Derd-i hicrāna mübtelā düşdüm

73. Cānuma geçdi firḳat-i cānān

Bağrımı yaḳdı āteş-i hicrān

74. Derd-i devri esīr-i künc itdi

Beni ‘ ālemlere gülünc itdi

75. Hasretiyle gözüm döker ḳan yaş

Görmeyeydüm bu demleri ey kāş

76. 'Aksine ḳā'il oldum āb içre

Yāri görsem n’olaydı ḩॅāb içre

77. El-amān ey maḥabbet-i cānān

El-amān ey meşaḳḳat-i hicrān

78. Hasret-i yāre gāyet olmaz mı

Bu firāḳa nihāyet olmaz mı

79. Bilmezem n'eyleyem nice ideyüm

Nereye başumı alup gideyüm

80. Nice günler garāib ü āvāre

Bì-dil ü bì-ḳarār u bì-çāre

81. Künc-i ġamda demādem ag̉lar iken

Nār-1 hasretle sīne dağlar iken

82. Var idi bir habīir-i aḥvālüm

Aña ma' lūm idi benüm hālüm

83. Maḥrem-i rāz u yār-1 gāārum idi

Kūşe-i ġamda gam-güsārum idi

84. Varup aḥvālümi dimiş yāre

O cefā-cūya ol sitemkāre

85. Saña bir mübtelā selām eyler

'Arż-1 ḥāliyle iḥtirām eyler

86. Cān u dilden muhibb-i șādıḳdur

Maẓhar-1 luțuñ olsa lāyıḳdur 
87. Șadme-i āhı 'ālemi yıḳdı

Nālesi çaḳ feleklere çıł̣dı

88. Saña inșāf virsün Allāhum

Ġarażuñ cevr ise yeter şāhum

89. Gūş idüp sözlerin șūret-i çīn

Gösterüp nāzikāne çīn-i cebīn

90. Dimiş aña tecāhülāne o dem

Baña ne virdi ālümüz bilsem

91. İtmesün ' āşıkum diyü beni yād

Kulum olursa eyledüm āzād

92. Böyle söyle dimiş o hem-rāza

Başlamış nice şive vü nāza

93. Gāh nāz u gehī niyāz olmış

Arada çoḳ niyāz u nāz olmış

94. Kaṣd-1 cevrile çoḳ kelām itmiş

Āhirinde velì selām itmiş

95. Dimiş ol guușṣa-mendi şād ideyüm

Yine vașlımla ber-murād ideyüm

96. Kalbini gamdan eyleyüp āzād

İdeyüm ḩāṭır-1 ḥazīnini şād

97. Nicedür ol gararībüñ ḥāli ${ }^{43}$

'Aceb ol derd-mendüñ aḥvāli

98. İntiz̄ārı irişdi pāyāna

Eylesün el-vedā $\bar{c}^{`}$ hicrāna

99. Bu ḩaberle o dilber-i țannāz

Eylemiş bendesin yine mümtāz

100. Kāmeti serv-i ser-efrāz olsun

'Ömri zülfi gibi dırāz olsun

\footnotetext{
${ }^{43} \mathrm{Bu}$ mısrada vezin aksamaktadır.
} 
101. Luṭ̂-1 yāre olınca erzāni

Eyledüm şevḳıle gazel-ḩَān $\bar{i}$

102. Gözlerüm yaşını sil Aḥmed Muhammed 'aşḳıına

Kadrümi bir kerre bil Aḥmed Muḥammed ‘aşḳına

103. Bāde-i āl olmasun ruhsāanuña reng-i ḥayā

Kendüñi itme huacil Aḥmed Muḥammed 'aşḳına

104. Serv-i dāmen-çīe ol seyl-i ‘ alāyıkẹdan hạazer

Cūy-1 șāfīi-veş çekil Aḥmed Muḥammed 'aşḳına

105. El-ḥažer şemşīir-i cān-te 'sīir-i āhumdan benüm

Ġayr bezminden kesil Aḥmed Muhammed 'aşḳıına

106. Olmasun ālūde-i çirk-āb-1 töhmet dāmenüñ

Pāk-rū ol muttaṣıl Aḥmed Muḥammed 'aşḳına

107. Maḥfil-i vașlunda yansun tünd-bād-1 hecr ile

Sönmesün ḳandīl-i dil Aḥmed Muḥammed 'aşḳına

108. Merḥamet eyle Naẓīm-i zāra aḥvāl-i dilin

Söylemek lāzım degil Aḥmed Muhammed 'aşḳına

109. Kā' be-i kūy-1 yāre țālib idüm

Görmege ol maḳāmı rāg̀ıb idüm

110. Cūy-veş sū-be-sū revān oldum

Cüst ü cū eyleyüp anı buldum

111. Nerede oldig̀ı̀n maḥalle-i yār

Bu rubā' ìyle eyledüm iş̧ ār

112. Hayretde iken firāḳla dīde-i cān

'Arẓ itdi yine 'izāā-1 pākin cānān

113. 'Aks eyleyeli cemāli ' aynile Naẓīm

Āyinneli Çeşme ${ }^{44}$ oldı çeşm-i giryān

114. Ey meh-i bedr-i şām-1 āmālüm

Mihr-i rahşān-1 șubḥ̣̂ iḳbālüm

\footnotetext{
${ }^{44}$ Arif Nihat Asya (ö. 1975) da İstanbul Göksu'da bulunan söz konusu Âyîneli (Aynalı) Çeşme'yi kendisine geçmişini, geçmişteki günlerini hatırlatması vesilesiyle bir rubaîsinde zikretmektedir. $b k$. (Asya, 1976, s. 178)
} 
115. Ey behişt-i melāḥat içre müdām

Kadi Ṭūbā ${ }^{45}$-ḳıyām u Sidre ${ }^{46}$-ḩrām

116. Ey cinān-1 cemāle huūr-1 sirişt

Lebi Kevșer ${ }^{47}$-nümūn-1 bāg̀-1 behişt

117. Ruhlaruñ verd-i bī-ḥazānumdur

Kāmetüñ nahll-i bā'g̀-1 cānumdur

118. Burc-1 bahtumda kevkebüm sensün

Mihr-i rūzum meh-i şebüm sensün

119. Gel gel ey bezm-i şevḳıme sākī

Cāndan var iken ramak bāki $\bar{i}$

120. Bāde-i vuṣlatuñla mest eyle

Bu humār-1 gamı şikest eyle

121. Keyf-i cām-1 lebüñle cūş ideyüm

Ṭoluñı 'āşıḳāne nūş ideyüm

122. Beni rüsvā-yı ' aşk iden sensün

Mest-i șaḥbā-yı ' aşḳ iden sensün

123. Kandasın ḳanda gel gözüm nūrı

Cigerüm yaḳdı āteş-i dūrī

124. Firḳatüñ cānı derd-nāk itdi

İntizāruñ dili helāk itdi

125. Şādmān it beni ḳudūmüñle

Maḳdem-i meymenet-lüzūmuñla

126. Ṭag tạga ḳavuşmasa meselā

Kavuşur ādem ādeme cānā

\footnotetext{
45 "Tûbâ müslüman milletlerin kültür, sanat ve edebiyatında kökü Hz. Peygamber'in makamı olan "vesîle" cennetinde dalları en üstten alta doğru bütün cennet tabakalarına ulaşacak şekilde tasavvur edilen ağaçtır." $b k$. (Uzun, 2012, s. 318)

46 “Tefsirlerdeki açıklamalar göz önüne alındığında sidre, Hz. Peygamber Allah'ın huzuruna varmadan önce Cennetü'l-me'vâda Cebaril'i yanında bıraktığı mübarek bir ağaçtır. Sidre aynı zamanda Cebrail'in makamıdır." $b k$. (Uzun, 2009, s. 152)

47 "Kevser, cennettte bir ırmağın adıdır. Edebiyatımızda tatı ve temiz, saf şarap manalarında kullanılmıştır." $b k$. (Kurnaz, 2013, s. 257)
} 
127. Nice bir firḳatüñle zār olayum

Nice bir zār u bī-ḳarār olayum

128. Beni ḳıldı nizār o mūy miyān

Ḳılca ḳaldı tenümde hecr ile cān

129. Çeşmüme sensiz oldı ḩॅ̄āb harām

'Acebā li'l-muhibbi keyfe yenām ${ }^{48}$

130. Gözümüñ yaşına nigāh eyle

Bağrımuñ başına nigāh eyle

131. Cān u dilden Naẓim-i ' āşıḳuñam

Bī-riyā bir muhibb-i șādıḳuñam

132. Mā'ilüm çeşm-i ' işve-bāzuña ben

Kạa 'ilüm bir nigāh-1 nāzuña ben

133. Hālüme çeşm-i ' işve-bāzuñ içün

Naẓar eyle nigāh-1 nāzuñ içün

134. Neyyir-i hüüsn-i bī-misāālüñ içün

Māh-1 tābān gibi cemālüñ içün

135. Serv-i bālā gibi ḳıyāmuñ içün

O șanavber-reviş ḩırāmuñ içün

136. Baña bildür günāhumı bileyüm

'Özrümi biñ hicābile diyeyüm

137. Bilürüm ey civān-1 sīm-berüm

Cürmüm oldur hemān seni severüm

138. Bu güneh besdür ol dil-figāre

Ki saña 'āşıḳum diye yāre

139. Ey büt-i deyr-i ' işve el-ḥāṣ̂l

Seni sevdiyse kāfir olmadı dil

140. Ehl-i buġż u ġarazda dīn olmaz

Kalb-i mü 'minde kibr ü kīn olmaz

\footnotetext{
${ }^{48}$ Seven nasıl uyur şaşarım!
} 
141. N'ola ' afv eyleseñ benüm günehüm

Kul ḩațāsız olur mı pādişehüm

142. Saña lāyık mı ey şeh-i hūōān

Huaṣm-1 dūn eyleye baña bühtān

143. I' '̇imād eyleyüp anuñ sözine

Baḳmaz olduñ bu bendenüñ yüzine

144. Șoḥbetüñden senüñ olam maḥrūm

Saña zâalim dine baña maẓlūm

145. Yiter Aḥmed bu cevrile ḥarekāt

Rūh-1 pāk-i Muhammede șalavāt

146. Ḥamdüli'llāh ki ey naẓīr-i melek

Gözlerüm varımış seni görecek

147. Şükrüli'llāh cemālüñi gördüm

Dest ü dāmenüñe yüzüm sürdüm

148. Bulmış idi kemāl-i ževḳ-1 viṣāl

Ġam-ı hicrāna da irişdi zevāl

149. Beni ref ${ }^{\tau}$ itdi hyākden keremüñ

Yiridür bașsa dīdeme ḳademüñ

150. Cilve-i nāzuña ḳumāş-1 niyāz

Olsun ey naḩl-i 'işve pāy-endāz

151. Ben niyāz eyledükce nāz eyle

Gāg gāh eyle az az eyle

152. Beni senden ayırmış idi ' adū

Başına geldi āhir ey meh-rū

153. Nice dem gerçi nā-murād oldum

Ṣıdḳ u kižbüm bilindi şād oldum

154. Oldılar rū-siyāh ehl-i nifāk

Oldı alnum açıḳ benüm yüzüm aḳ 
155. Ḥāl-i hașm-1 denī tebāh oldı

Bahtı ber-geşte kārı āh oldı

156. Baña itmişdi itdügin buldı

Şimdi benden o beş bed-ter oldı

157. Baña Hạ 'ạḳıbet o nā-merdi

Nice istersem öyle gösterdi

158. Yolına geldi uggradı āha

Kendüsi düşdi ḳazduği çāha

159. ' 'Āleme hasb ü hāā olup bu maḳāl

Didiler Dāstān-ı Hecr ü Vișāl

\section{Kaynaklar}

Aktaş, Ş. (2015). Anlatma esasına bağlı edebî metinlerin tahlili. Ankara: Kurgan Edebiyat.

Aktaş, Ş. (2005). Roman sanatı ve roman incelemesine giriş. Ankara: Akçağ Yayınları.

Akün, Ö. F. (2013). Divan edebiyatı. İstanbul: İsam Yayınları.

Arslan, M. (2007). Türk edebiyatı'nda hamse, Türkiye Araştırmaları Literatür Dergisi, 5(9).

Asya, A. N. (1976), Rubâiyyât-ı Ârif-I. İstanbul: Ötüken Yayınevi.

Ateş, A. (1971). Mesnevi. İslâm ansiklopedisi C 8, İstanbul: MEB Yayınları.

Ayan, H. (1979). Divan edebiyatında hamseler. Ä̈ Edebiyat Fakültesi Araştırma Dergisi (Ahmed Caferoğlu Özel Sayısı).

Ayan, H. (2011). Leylâ vü Mecnûn. İstanbul: Dergâh Yayınları.

Behar, C. (2010). Şeyhülislâm'ın müziği 18. yüzyılda Osmanlı/Türk musikisi ve Şeyhülislâm Es'ad Efendi'nin Atrabü'l-Âsâr'ı. İstanbul: Yapı Kredi Yayınları.

Bursalı Mehmed Tâhir (2009). Osmanlı Müellifleri I-II-III. (haz. Cemal Kurnaz-Mustafa Tatçı). Ankara: Bizim Büro Yayınevi.

Çağliişlek, A. (1991). Yahya Nazîm Divanı II (İnceleme-Metin). Yayımlanmamış yüksek lisans tezi. Kayseri: Erciyes Üniversitesi, Sosyal Bilimler Enstitüsü.

Çapan, P. (2005). Tezkire-i Safâyî. Ankara: AKM Başkanlığı Yayınları. 
Çelebioğlu, Â. (1999). Türk edebiyatında mesnevi [XV. Yüzyıla Kadar]. İstanbul: Kitabevi Yayınları.

Çetin, N. (2009). Roman çözümleme yöntemi. Ankara: Öncü Kitap.

Demirci, K. (2001). Kafdă̆ı. DïA C. 24, İstanbul: TDV Yayınları.

Dilçin, C. (1991). Fuzulî’nin bir gazelinin şerhi ve yapısal yönden incelenmesi. Türkoloji Dergisi. C. 9, S. 1.

Doğan, NUR M. (2002). Hüsn ü aşk. İstanbul: Ötüken Yayınları.

Eliaçık, M. (2005). Edebiyat tarihimize 1şı tutan bir eser: Atâ Tarihinin 4-5. Ciltleri. İlmî Araştırmalar, 20.

Ertürk, Ş. K. (1996). Yahya Nazîm Divanı V (İnceleme-Metin). Yayımlanmamış yüksek lisans tezi, Kayseri: Erciyes Üniversitesi, Sosyal Bilimler Enstitüsü.

Gümüş, N. (1992). Yahya Nazîm Divanı I (İnceleme-Metin). Yayımlanmamış yüksek lisans tezi, Kayseri: Erciyes Üniversitesi, Sosyal Bilimler Enstitüsü.

İnce, A. (2005). Tezkiretü 'ş-Şuarâ Sâlim Efendi. Ankara: AKM Başkanlığı Yayınları.

İpekten, H. (2010). Nazîm şekilleri ve aruz. İstanbul: Dergâh Yayınları.

Kam, R. F. (1933). Bestegâr Şair Nazîm. İstanbul: Hilâl Matbaası.

Kartal, A. (2013). Doğu’nun uzun hikâyesi Türk edebiyatında mesnevi. İstanbul: Doğu Kütüphanesi.

Kurban, A. (1992). Yahya Nazîm Divanı IV (İnceleme-Metin). Yayımlanmamış yüksek lisans tezi, Kayseri: Erciyes Üniversitesi, Sosyal Bilimler Enstitüsü.

Kurnaz, C. (2013). Ahmet Talat Onay, açıklamalı divan şiiri sözlüğü. Ankara: Kurgan Edebiyat.

Kutlar Oğuz, F. S. (2014). Mehmed Nebîl Bey ve Hicr ü Visâl'i. Turkish Studies, 9(12).

Küçükaşc1, M. S. (2013). Zemzem. DİA C 44, İstanbul: TDV Yayınları.

Onur, N. (1991). Hamdi, Yûsuf u Züleyhâ. Ankara: Akçağ Yayınları.

Özalp, N. (1986). Türk mûsikîsi tarihi. Ankara: MEB Yayınları.

Pala, İ. (1991). Ankâ (Edebiyat). DİA C 3, İstanbul: TDV Yayınları. 
Pala, İ. (2012). Ansiklopedik divan şiiri sözlüğ̈̈. İstanbul: Kap1 Yayınları.

Selçuk, B. (2008). Divan şiirindeki ses ve ahenkle ilgili sanatlara genel bir bakış. Ulusal Eski Türk Edebiyatı Sempozyumu, Adıyaman.

Şentürk, A. A. (2002). XVI. asra kadar Anadolu sahası mesnevilerinde edebî tasvirler. İstanbul: Kitabevi Yayınları.

Şimşek, M. (2007). Yahya Nazîm Divanı III (İnceleme-Metin), Yayımlanmamış yüksek lisans tezi, Kayseri: Erciyes Üniversitesi, Sosyal Bilimler Enstitüsü.

Tekin, M. (2007). Roman sanatı. Ankara: Hece Yayınları.

Uzun, M. (1991). Aşk (Edebiyat, Kültür ve Sanat). DİA C 4, İstanbul: TDV Yayınları.

Uzun, M. (2009). Sidretü'l-müntehâ (Edebiyat). DİA C 37, İstanbul: TDV Yayınları.

Uzun, M. (2012). Tûbâ (Kültür ve Edebiyat). DİA C 41, İstanbul: TDV Yayınları.

Uzun, M.-ÖZCAN, N. (2006). Nazîm. DIA C 32, İstanbul: TDV Yayınları.

Ünver, İ. (1986). Mesnevi. Türk Dili Türk Şiiri Özel Saylsı II (Divan Şiiri), 415-416417/Temmuz-Ağustos-Eylül, Ankara.

Yahya Nazîm (1257). Divan-ı Belâgat-unvân-ı Nazîm. İstanbul: Takvîm-i Vakâyi’ Matbaası.

Yazıcı, T. ve Kurnaz, C. (1997). Hamse. DIA C. 15, İstanbul: TDV Yayınları. 